Notre Dame Law School

NDLScholarship

Journal Articles

Publications

2005

\title{
Response to Endicott: The Case of the Wise Electrician
}

Gerard V. Bradley

Notre Dame Law School, gerard.v.bradley.16@nd.edu

Follow this and additional works at: https://scholarship.law.nd.edu/law_faculty_scholarship

Part of the Legal History Commons

\section{Recommended Citation}

Gerard V. Bradley, Response to Endicott: The Case of the Wise Electrician, 50 Am. J. Juris. 257 (2005).

Available at: https://scholarship.law.nd.edu/law_faculty_scholarship/850

This Response or Comment is brought to you for free and open access by the Publications at NDLScholarship. It has been accepted for inclusion in

Journal Articles by an authorized administrator of NDLScholarship. For more information, please contact lawdr@nd.edu. 


\title{
RESPONSE TO ENDICOTT: THE CASE OF THE WISE ELECTRICIAN
}

\author{
GERARD V. BRADLEY
}

Timothy Endicott tells the tale of the "wise electrician." Speaking as a homeowner, I should be pleased to hear about the moderately competent, reasonably affordable electrician. But that is not what Timothy has put on offer. Let us talk then about his much more interesting guy.

The main activities of the Wise Electrician are two. One is that he installs legally required Grade 5 insulation in everyone's home save one. The second is that on his own ceiling light circuits he uses Grade 4 insulation. Number 4 is cheaper to acquire and, in his professional judgment, it is safe. We are not invited to infer that the Wise Electrician's abode is unique; number 4 would apparently be safe in many homes, and just as cheap for their owners. In fact, the Wise Electrician would install Grade 4 in those houses, too, but for one fact: it would be illegal. What makes our man so interesting is that it is illegal to install Grade 4 in his house too. The law says: Grade 5 for "all home wiring" and that's that. No exceptions listed.

Endicott says that the Wise Electrician breaks the law at home because it "cannot help him to act for the common good (or for any more particular good)." At home the Wise Electrician reasons "that he does not need the service that the [Grade 5] law provides to the community, and that his compliance would do nothing to promote the effectiveness of that service, and his violation of the legal obligation does nothing to hinder it, and violating that legal obligation will save a little money." Installing number 5 would be a pointless expense, a waste of money. And our man's private defiance of the code will lead no one to infer that the regulation does not matter. No one will know.

Out and around the Wise Electrician adheres to the building code even though he considers it to be-indeed, he knows it to be-overprotective. He adheres to the law because, according to Endicott, the Wise Electrician knows that, though number 5 is not necessary, it is safe. He also holds that that the uniform standard prevents "dangerous mistakes" by electricians less seasoned than he, and that it will be easier and more efficient to enforce the uniform law. We can see that where he or another electrician of his skill and judgment is concerned, installing Grade 5 in ceilings is often a waste of money. But, outside his home, he installs it anyway.

Why? The Wise Electrician obeys the law outside his home to avoid scandalizing the law-abiding. Endicott also asserts that code compliance is an implicit term of his agreement with customers. This second reason is a little 
rickety, and its weakness infects the first. I would not deny that without more, customers may expect newly installed wiring to be up to code. But what if there is more? Why should we think it wrong for the Wise Electrician and his more sophisticated customers to make explicit agreements to install number 4 ? If it is eyes open all around and every mouth agreed to be shut, there is no evident unfairness to the parties involved and no real risk of scandal to the law-abiding.

As to the first reason: Endicott assumes, I think, that law-abidingness as a general social habit is more brittle than in fact it is. Consider any legal requirement which is obviously overprotective. An example is a rule which requires bar owners to demand two forms of picture ID from anyone who asks for a drink but who looks to be younger than 30 . The drinking age is 21 . Or a law that says anyone who volunteers even once to chaperone a kids' afterschool outing must be fingerprinted and supply two character references. (Notice that even where these practices are not explicitly required by statute, they may be practically necessary to avoid civil liability in case things go awry.) Though compliance with these effective legal requirements may be common due to fear of adverse consequences, most people (even most who comply) realize that these rules are-how should one say it?--a bit hysterical. Widespread disregard of these requirements would not, I think, lead citizens to believe that law-abidingness in general is optional. Quite the opposite may be the case: quiet disregard of some, maybe many, overprotective laws may be necessary to maintain widespread observance of wise laws. It may be, in other words, that people retain the respect they do for those laws they do observe, partly by judging that they are not meaningless or perverse restraints, as are those few laws which the same people violate with impunity and without pangs of regret.

Now, I offer the preceding observations as matters of fact about social attitudes towards the law, and not as an argument for breaking laws. In fact, I argue against these attitudes below: I think people have a moral obligation to obey the law as such. My point here is, rather, insofar as Endicott justifies the Wise Electrician's law abidingness outside the home by fear of scandal, I think the justification is weak. Law-abidingness as social habit or attitude is not that brittle. And I argue (below) against the Wise Electrician lawbreaking at home on grounds of fairness, not social consequences.

Endicott draws this moral from the story of the Wise Electrician: there is no general moral obligation to obey the law. People "do not generally need to obey the law. They need to do so when it provides the help it is capable of, and they need to do so when doing otherwise would wrongly damage its ability to provide that help." He deploys the Wise Electrician to advance and support this position, which places him-as Endicott describes-in 
disagreement with John Finnis on the question: "does the law have the moral force that it claims?" Endicott paraphrases Finnis's answer from Natural Law and Natural Rights (NLNR): "there is a general moral obligation to obey the law."

I do not know whether Finnis in NLNR answers the precise question posed by Endicott: does the law have the moral force that it-the law-claims for itself? I do not know whether Finnis answers that question there because I do not know (in fact, I tend to doubt) that Finnis wonders at all about what the law claims-if it claims anything-about a moral obligation to obey it. Nonetheless, a natural law theory of law does characteristically affirm that there is a general moral obligation to obey the law; Finnis affirms that there is a general moral obligation to obey the law, and Endicott denies that there is. And so we have a real dispute about an important question.

I wish here to register some observations about the matter.

Finnis holds that there is a presumptive moral obligation to obey the law, which obligation may be defeated by moral considerations. One is generally obliged to stop for red lights because it is the law that red means stop. But one need not-and one should not-stop on red in emergencies when it is safe to pass through the intersection. One should not steal, save where one's necessities lie within the abundance of others and there is no other way to satisfy the needs of the poor than "stealing" from the rich. Our Wise Electrician should install Grade 5 wiring in people's homes, save perhaps in the rare case where Grade 4 is safe and is readily available, where Grade 5 is not available or has become very expensive, and where the homeowner possesses very modest means. In a case like this one the Wise Electrician may, I think, install Grade 4 so long as he fully discloses the risk of possible inspection and sanction to the owner. The Wise Electrician may be obliged to install Grade 4 if almost any other electrician would do so out of sympathy for the homeowner, but where many of them are less competent than our guy. For our guy to do otherwise might unfairly impose some risk upon the hapless customer.

Apart from any such exceptional circumstances, however, I think (as does Endicott) that our guy is morally obliged to install Grade 5 in customers' homes. I think that he is obliged to install it in his own house, too. Herein lies my disagreement with Timothy Endicott.

Before turning to the reasons for my disagreement, I should like to address two preliminary matters. One is that, although there are suggestions to the contrary in Endicott's text, I take it to be the case that he is not arguing that the wiring requirement exceeds the just limits of government. I take it that he is not arguing against the provision as one would argue against a law which prescribed, say, the paint color of one's ceiling - that the law crossed the line 
into pure legal paternalism. Endicott does refer to the law's "limited jurisdiction" over the "wise electrician," and to the subsidiarity of law. He appeals - it seems - to the claim that the law as applied to our man's home does not implicate the common good at all. But this possible interpretation of part of Endicott's argument is contrary to his main thrust, which is that this man's compliance with the law in this particular case does not advance the common good. That claim is quite different from the claim that home wiring is none of the law's business, that the common good is not implicated by a particular legal rule.

A "raw paternalism" reading of Endicott's argument is also inconsistent with his judgment that it is right for the "wise electrician" to obey the law all over town. The kings and queens of those castles would seem to possess the same sovereignty over their abodes as does the Wise Electrician over his.

In fact there is a common good in safely wired houses. It is never the case that wiring decisions are entirely self-regarding (and they are scarcely selfexpressive): electrical fires occur due to faulty wiring and have the potential to spread to neighboring structures; municipal fire departments invariably respond to fires no matter what the perceived cause, at peril to themselves and to others in their speeding path; invited guests and uninvited lawful visitors do not consent to be toast for an iconoclastic homeowner's blaze and thus are owed duties of care; insurance rates are based upon uniform standards for wiring and the like, so that saying there is no proper legal interest in home wiring is to consign everyone to dramatically increased insurance costs (because fire risks could not be reliably calculated by insurers). A man's home may be his castle, but he has no right to burn it down - or to take firesafety risks with it-at his pleasure.

One more caveat: I take it to be the case that the wiring world is not Manichean, that it is not a universe in which Grade 5 is simply safe, and that Grade 4 is not. Endicott is no wiring Manichean. He describes a more nuanced world in which "experts" can identify those "certain" building conditions in which Grade 4 is safe; "less expert electricians" are prone to "dangerous mistakes." The uniform standard, he says, greatly reduces the latter sort of risk. But it would not seem to eliminate it: Grade 5 is safe for all "ordinary household wiring" (my emphasis). In other words, the world of wires contains within it shades of risk which expert judgment can diminish but never quite eliminate. In this more nuanced world the uniform standard (Grade 5 everywhere) is not just a straight-on "safety" provision. It is also about risk shifting and management-and there is no evidence (nor a claim) that our electrician's expertise extends to risk management.

Or to the other common goods implicated by the wiring code. Consider the possible economic injury to his own competitors who are (for various reasons) 
unwilling to violate the Code. On the supposition that there is a complex "black market" in sub-code wiring - with prices reflective of the various risks involved - competition with on-market comparable goods and services is greatly skewed. (There are many real-world examples of these effects.) There might even be honorable reasons for public authority to create a level playing field of competition among electricians and among makers of insulation. For example, the leading maker of Grade 4 might be a bad corporate citizen, perhaps a foreign firm which exploits its workers. Because of a free-trade agreement it might be impossible to effectively prevent importation of Grade 4 insulation, but at least the domestic demand can be reduced. In the real world it is often the case that rules such as those affecting insulation are often, and often largely, more or less honorable market regulations or attempts to redistribute wealth. (Sometimes, however, they are self-serving acts of guild interests.)

There are therefore additional reasons for complying with the law when working outside the home: resale of customers' homes later may be impossible without bringing them up to code; inspections can be triggered by other events, with similar upgrades ordered. In both cases homeowners would pay twice for the same job; their insurers might balk at paying any claim related to an electrical fire, even if its relation to the sub-code wiring is uncertain. Perhaps some of these possibilities can be "priced," the various bets hedged, and some fair arrangement obtained. But not always, with all customers.

The reason for my disagreement with Endicott about a general moral obligation to obey the law is-at least insofar as the case of the Wise Electrician provides a test--that Endicott needs him to be also a Wise-very Wise-Statesman too. This he (the Electrician) is not. The Wise Electrician understands the governing law to be a straightforward proposition about safety. I think it is not. Even as far as safety alone is considered it is a more complicated matter of legally assigning and managing risk and the responsibility therefore. Now, a law which actually said that licensed electricians were exempt from the Grade 5 requirement in their own homes would, I submit, have been reasonable and not unfair to their homeowners. Many laws concerning safety operate something like that: fire extinguishers, smoke alarms, fire escapes, insulation requirements often distinguish sharply among commercial and residential and rental properties. In this case, a further distinction for certain craftsman-occupied homes could be defended as a judgment that the smaller risk of mistake or fire and the greater sophistication of the owner willing to assume risk make it-all things considered-prudent to treat the "wise electrician" differently. He knows how the appliances are used and situated, how much juice they require, and any changes in their 
configuration or power will be made by him and in accord with his expert judgment. A reasonable legislator could also judge that, when it comes to the "wise electrician" and his own, nothing less than what the job requires will be done. A reasonable legislator could judge, too, that even the "wise electrician" on other jobs could be talked into taking a chance by a homeowner of modest means, but one who does not know enough to prudently gauge and protect against the risks of Grade 4 wiring, and who will not adjust electricity consumption as he goes.

Hart said, and Endicott agrees, that living under the rule of law requires the "sacrifice of personal interest" on everyone's part. Endicott further quotes Hart to say that the demands for these sacrifices are contained in rules which prohibit violence and which require "truthfulness, fair dealing, and respect for promises." These are relatively small sacrifices, in that these legal requirements ask very little of persons which critical morality does not already require of them. The bigger sacrifices which law distinctively requires of us are different, though close to the matter at hand: judgments about what laws are for and about how effectively a particular law serves its diverse ends.

A general obligation to obey the law arises, then, centrally from the general need for people within a legal system to refrain from judging for themselves exactly what a law is for and how effectively a particular legal rule promotes cooperation toward that end. This restraint upon judgment and action based upon one's own unrestricted practical reasoning is the pillar of lawabidingness. The Wise Electrician thinks that by acting safely-as he judges it - he is being fair to others. But it is rather by acting on his judgment (about safety) contrary to the law's judgment that he acts unfairly. He indulges his own will in a way that others deny to themselves. 